\title{
ERRATUM
}

\section{From Autochthony to Violence? Discursive and Coercive Social Practices of the Mai-Mai in Fizi, Eastern DR Congo}

Judith Verweijen

doi:10.1017/asr.2015.42. Published by Cambridge University Press, September 1, 2015.

Two errors were made in the references for this article:

1. The name of Scott Straus is misspelled as "Strauss" both in the text and in the reference list.

2. The publication year of Brass' work (1997) is missing in the reference list.

The publisher regrets this error.

\section{Reference}

Verweijen, Judith. 2015. Autochthony to Violence? Discursive and Coercive Social Practices of the Mai-Mai in Fizi, Eastern DR Congo." African Studies Review 58: 157-180. doi:10.107/asr.2015.42. 